УДК [94: $314.15: 316.7]: 070$ (477) «1920»

DOI: https://doi.org/10.33782/eminak2019.2(26).305

\title{
ЧАСОПИС УКРАЇНСЬКОЇ ЕМІГРАЦІЇ «ТРИЗУБ» ЯК ДЖЕРЕЛО ВИВЧЕННЯ СОЦІОКУЛЬТУРНИХ ПРОЦЕСІВ І ПОВСЯКДЕННЯ В УКРАЇНІ ПІД ВЛАДОЮ БІЛЬШОВИКІВ (1920-ті рр.)
}

\author{
Олександр Вовк \\ Сумський державний педагогічний університет імені А.С. Макаренка (Суми, Україна) \\ e-mail: o.v.vovk@gmail.com \\ ORCID: https://orcid.org/0000-0001-7071-8964
}

\begin{abstract}
У статті проаналізовано тижневик української еміграції «Тризуб» в якості джерела вивчення соціокультурних процесів і повсякдення в Україні під більшовищькою владою у 20-ті роки ХХ ст. З'ясовано, що тематика частини публікацій часопису стосувалася різноманітних сфер життя украӥнської спільноти в УСРР: розвитку культури, внутрішнього світу людини, сприйняття дійсності, тлумачення змін у природі крізь призму суспільних перетворень, відносини мешканців міста і села, становище різних прошарків суспільства.
\end{abstract}

Ключові слова: журнал, тижневик, соціокультурний процес, повсякденне життя, більшовики

У 1925-1940 рр. в Парижі у середовищі української еміграції виходив громадськополітичний, літературно-мистецький тижневик «Тризуб». Часопис був неофіційним органом Державного центру УНР на еміграції. Завданням журналу було відстоювання ідеї української державності, привернення світової громадськості до української проблеми. Тижневик був заснований $з$ ініціативи С. Петлюри, В.Прокоповича, П. Чижевського. Редактором часопису тривалий час був В.Прокопович (19251939 рр.), а згодом - О. Шульгин (1940р.).

Матеріали, що розміщувалися у «Тризубі», були присвячені проблемам життя української еміграції, стосувалися соціально-політичних, етнонаціональних, історичних, економічних, мистецьких питань. У цьому виданні публікувалися українські політичні та громадські діячі, документи Державного центру УНР в екзилі, рецензії, хроніка1․ Значна кількість матеріалів тижневика була присвячена не лише подіям у світі, але й поточному становищу в УСРР, що дає підстави розглядати часопис «Тризуб» як джерело вивчення історичного процесу в Україні під владою більшовиків.

Проблема української еміграційної преси знайшла своє висвітлення в історіографії. Висвітлювалася роль «Тризуба» у контексті громадсько-культурного, освітнього, жіночого руху української еміграції². Історики відзначають роль тижневика в актуалізації завдань української військової еміграції та молоді, висвітленні зовнішньоінформаційної акції ДЦ УНР та боротьбі з ворожою пропагандою, ролі журналу у розбудові «єдиного фронту» демократичної періодики, участі у міжпартійній полеміці,

\footnotetext{
1 Ясь О.В. «Тризуб» // Енциклопедія історії України: У 10 т. / Редкол.: В.А. Смолій (голова). Т. 10: ТЯ. Київ: Наукова думка, 2013. С. 151.

${ }^{2}$ Наріжний С. Українська еміграція. Культурна праця української еміграції між двома світовими війнами. Частина перша. Прага, 1942. С. 108, 249.
} 
з'ясуванні проблем міжнаціональних відносин³. Історики також розглядали «Тризуб» у контексті діяльності С. Петлюри ${ }^{4}$, розслідуванні обставин його загибелі5, пропагуванні ідеї української державності у форматі УНР'. Дослідники характеризують видання як «точку перетину всіх прихильників Директорії і Петлюри... Цей журнал об'єднав генералів УНР Удовиченка, Осецького й українських інтелектуалів Дорошенка, Лотоцького, Мазепу, Славінського»7.

Журнал «Тризуб» вивчався дослідниками також і в контексті участі уряду УНР в еміграції у прометеївському русі (політичному, культурному, інтелектуальному русі, що розгортався у 1920-1930-х рр. в Європі за ініціативи Ю. Пілсудського) ${ }^{8}$. Більшість істориків розглядали «Тризуб» у контексті життя української еміграції, а не як інформативне джерело про соціокультурні процесі в Україні під більшовицькою окупаці$\epsilon ю$ Нашим завданням $\epsilon$ довести, що вказаний часопис можна розглядати як джерело вивчення повсякдення українців у складі УСРР, соціальних, культурних процесів під більшовицькою окупацією.

Серед сучасних напрямів розвитку історичної науки важливим $\epsilon$ історія повсякдення. У цьому напрямку приділяється більшої ваги дослідженню умов життя, праці, відпочинку людини, особливостям її харчування, лікування, адаптації до середовища, соціально-політичні погляди, усталені норми поведінки. Звертаючись до матеріалів тижневика «Тризуб», знаходимо багато інформації про соціокультурні процеси в Україні, повсякденне життя українців під більшовицькою владою.

Важливою у цьому контексті для нас $є$ рубрика на сторінках тижневика «Лист $з$ України». Авторство публікацій належить людині, що укрилася за псевдонімом «Степовик». У числі 17 від 7 лютого 1926 р. у вказаній рубриці йдеться про різні аспекти повсякдення українців в умовах непу. Зокрема, вказується на популярність торгівлі серед усіх прошарків населення та різних об’єднань, на що влада у даний момент не чинить перешкод. Проте, вказується про невідповідність цін на збіжжя та промислові продукти, що змушує селян бідувати. Восени влада скуповує зерно за дешевими цінами, а згодом з прибутком продає за кордон. Селяни намагаються таким чином переховувати збіжжя, а не продавати його державі. Мешканці міст намагаються заздалегідь купити більше хліба, бо ціна на нього невдовзі має зростия. Про проблему невідповідності цін на збіжжя та промислові товари в УСРР мова йде на сторінках тижневика «Тризуб» в в наступних випусках ${ }^{10}$.

Цікавим $€$ опис нового суспільного прошарку, який породили комуністичні експерименти в економіці: «У містах у нас зараз не диво зустріти скільки завгодно бур-

\footnotetext{
3 Богуславський О.В. Преса міжвоєнної української еміграції і боротьба за незалежність України: історичний шлях, досвід, дискусії. Монографія. Запоріжжя: Просвіта, 2008. С. 231-236, 247, 255, 273, 275-279, 284, 308-310, 313; Маврін 0. Журнал «Тризуб» у громадському й політичному житті української еміграції у Франції міжвоєнного періоду // Наукові записки. Збірник праць молодих вчених та аспірантів. Т. 20. Київ, 2010. С. 346-356.

${ }^{4}$ Косик В.М. Симон Петлюра. Львів: НТШ, 2000. С. 63.

5 Гриненко О.О. Матеріали журналу «Тризуб» про розслідування вбивства С. Петлюри (19261928 рр.) // Український історичний журнал. 2009. Вип. 3. С. 34-43.

6 Животко А. Історія української преси. Мюнхен, 1989-90. С. 284.

7 Савченко В. Симон Петлюра. Київ: Нора-Друк, 2016. С. 450-451.

8 Піскун В. Участь уряду УНР в еміграції у прометеївському русі: політичний, територіальний та індивідуальний виміри // Славістична збірка. 2015. Вип. 1. С. 232-247.

${ }^{9}$ Степовик. Лист з України // Тризуб. 1926. Ч. 17. С. 8.

10 Степовик. Лист з України // Тризуб. 1926. Ч. 22. С. 12-16; Вітер з України // Тризуб. 1926. Ч. 48. C. 10 .
} 
жуазії, так званих «неповців», у золоті, в брильянтах, у дорогих шубах без ріжниці проти ранішого. Ця нова буржуазія стоїть дуже близько до комуністів, з ними гандлює і тому почуває себе, як у Христа за пазухою...»11.

У вказаній замітці, попри невеликий її об’єм, підіймаються найрізноманітніші питання життя українців. Наприклад, вказується про те, що саме боротьба українських селян і робітництва у роки повстань спонукали до того, що влада здійснила певні поступки щодо національних прав українців. Вказується переконання автора про те, що українське село є неприступним для російської культури, і влада змушена дедалі більше друкувати літератури українською мовою, особливо підручників. У мові оповідача з'являється вислів «нові українці» щодо лояльного до влади носія української мови та культури. Автором публікації висловлюється думка про неминучість українізації, i, навіть, висловлюється твердження, що «большевики по суті «похирили» свій «комунізм» і пливуть за течією, до невідомих берегів...»12. У публікаціях тижневика, навіть, висловлюється думка, що «національна свідомість глибоко і широко пройняла народні маси... Люди по містах встидаються розмовляти по російськи, а на селах побоюються» ${ }^{13}$.

На противагу цьому дописувачами «Тризуба» в еміграції досить широко розглядалися й аналізувалися перспективи української національної політики під більшовицьким режимом. Закордонні автори висловлювали думку у публікаціях: якщо буде взяте за основу зовнішнє представлення України на міжнародній арені як суверенної незалежної республіки, а у внутрішній політиці буде переважати відверте знищення української культури та мови, то національні перспективі досить невідрадні. Як видно, автори в еміграції реальніше дивилися на «українізацію» та передбачали, що вона може закінчитися антиукраїнським терором ${ }^{14}$. Про нещирість більшовицької українізації йдеться на сторінках «Тризуба». Вказується про те, що не варто деяким українцям-емігрантам захоплюватися нею як таким собі «новим курсом», а також не слід вірити у те, що комуністичні чиновники в Україні постануть проти Москви - це цілковита фантазія 15.

Для викачування якнайбільшої кількості грошей з населення, влада вдається до зниження цін на горілку, що, на переконання «Степовика», призводить до сумних наслідків, а також ширенню розпусти: «один мій знайомий, що побував недавно в Катеринославі, повідомляє, що там на Нагорній вулиці відчинено «1-ий Радянський Дім Терпимости»16. Якщо останню інформацію можна сприймати критично, то цілком правдоподібними здаються твердження автора про поширення побутової проституції, особливо, серед дітей. «Головні причини збільшення проституції - це безробіття серед жінок, бездомність, а також де-котрі ненормальності в побутових 3'явищах нашого життя, хиткість шлюбу і т.д.»17. Про проблему поширення аморальності в українському суспільстві йдеться на сторінках тижневика неодноразово. Вказується на поширення розпусти серед селян, а, особливо, у містах, велику кількість безпритульних дітей. Розірвання шлюбу стає простою формальністю, що зни-

\footnotetext{
11 Степовик. Лист з України // Тризуб. 1926. Ч. 17. С. 9.

12 Степовик. Лист з України // Тризуб. 1926. Ч. 17. С. 9.

13 Вітер з України // Тризуб. 1926. Ч. 48. С. 11.

14 Богуславський О.В. Преса міжвоєнної української еміграції і боротьба за незалежність України: історичний шлях, досвід, дискусії. Монографія. Запоріжжя: Просвіта, 2008. С. 317.

15 Г.Ш. До дев’ятих роковин большевизму // Тризуб. 1926. Ч. 55. С. 22.

16 Степовик. Лист з України // Тризуб. 1926. Ч. 17. С. 10.

17 Степовик. Лист з України // Тризуб. 1926. Ч. 33. С. 27.
} 
жує його авторитет. 3 того виходить, що чоловіки й жінки ставляться до шлюбу украй легковажно. Особливу ж аморальність плекають комсомольці, які в селах не $\epsilon$ численними, але у містах їх багато ${ }^{18}$.

На переконання «Степовика», українське селянство стоїть у культурному відношенні вище за російське, воно є основним продуцентом молодого покоління, що сприяє збільшенню народжуваності. Це лякає комуністів, а дехто з них навіть висловлюється проти «многоплодности» ${ }^{19}$, остерігаючись таким чином демографічного вибуху в українців, яких і так важко поставити під контроль, а в подальшому може стати ще складніше.

У рубриці «Лист з України» на шпальтах тижневика мова йде про стан освіти в українському селі, про матеріальне становище вчительства. Вказується на те, що школи являють собою брудні будинки зі зламаними меблями. Непослідовні експерименти у галузі освіти, що спираються на закордонний, зокрема американський досвід, лише шкодять навчанню дітей. Натомість на першому місці стоїть політична освіта, історія ВКП(б). Учитель у школі не має жодного впливу на дітей, бо вони перебувають під впливом комсомольців - «шпигунів від партії»20. Заробітна плата вчителів (25-30 карбованців) $є$ мізерною відносно цін на товари, а його освіта не береться до уваги взагалі, бо вагу мають лише політичні переконання. «Степовик» вказує на той факт, що «найсвідоміші українці являються сільські вчителі, потім службовці спілок, споживчих товариств»21. 3 цього виходить, що влада не дбає про матеріальний стан вчительства, бо не має до нього довіри. Як вказує інший автор у рубриці «Лист з України», «найгірше, що завели більшовики в шкільній справі, це партійність і вузько партійне політиканство. Приміром, в школи стараються не приймати селянських дітей, хоч по закону вважається, що навчання для всіх. Отаку болячку має той Захарченко, що по-над яром сидить. Його хлопець здав добре іспит в Н-ську професійну школу, педагогична рада прийняла але «совіт нечестивих» виключив із школи: кажуть, це с[е]лянин, ми б хотіли робітника. Оце той союз робітника з селянином, називається змичка, бодай їх за тім'я смикало. А скільки крику «школа й просвіта для села, геть темноту». А на повірку не те...»²2. Як бачимо, інформація про суперечності між робітництвом і селянством в Україні, про нерівне їхнє становище потрапляла й на сторінки закордонної української преси.

Автор «Листів з України» зазначає, що скрізь в Україні набуває поширення доносительство («шпигунство»). Це призводить до того, що всі бояться один одного, не довіряють. Особливо ж загрозливою у цьому значенні набуває ситуація в селах. Роль колишнього дворянства за теперішніх умов виконують так звані «незаможники». Найбезправнішими у селі є заможні господарі, їх обкладають великими податками, їхнім дітям закрито дорогу до школи, обмежено право у суді, заборонено обирати їх на громадські та державні посади. 3 огляду на те, що чітких визначень приналежності до певного прошарку не існує, - все залежить від того, як вирішать «сильні миру цього на селі»23. Станом на 1930 р. тижневик пише про те, що в УСРР «українське населення як у містах, так і по селах тероризовано й перебуває під вічною загрозою

\footnotetext{
18 Вітер з України // Тризуб. 1926. Ч. 48. С. 11.

${ }^{19}$ Степовик. Лист з України // Тризуб. 1926. Ч. 42. С. 18.

20 Степовик. Лист з України // Тризуб. 1926. Ч. 22. С. 14.

21 Степовик. Лист з України // Тризуб. 1926. Ч. 22. С. 15.

22 Буркун. Лист з України // Тризуб. 1927. Ч. 17-18. С. 31.

23 Степовик. Лист з України // Тризуб. 1927. Ч. 45. С. 22.
} 
впасти жертвою шпигунства й провокації. Розмов на актуальні теми сучасности всі рішуче уникають, бо ніхто нікому не вірить ані на крихту, кожний боїться впасти жертвою цього свого довір'я...»24.

Автор «Листів з України» часом глузує з невміння більшовиків господарювати, що часом призводить до курйозних випадків. Наприклад, автор пише про те, що у низці торгових закладів в Україні з'являється величезна кількість незатребуваного посуду, а до Полтави навіщось було завезено 40 тисяч нічних горщиків, з чого, навіть, радянська преса глузувала25.

Багато інформації про соціокультурні явища й особливості повсякдення в Україні під більшовицькою владою міститься у розділі «Тризуба» - «Хроніка». У березні 1926 р. тижневик повідомляв про те, що настрої селянства в Україні на перевиборах схиляються у бік заможніших, викликаючи занепокоєння Москви. У селах поширюється ненависть до активістів і комуністів, що призводить до їх загибелі (Конотопщина, Роменщина) ${ }^{26}$. Ще загрозливішою стає ситуація через рік. На Чернігівщині поширюються вбивства активістів через вікно. Як повідомлялося у тижневику «Тризуб» у лютому 1927 р. на підставі вивчення комуністичної преси, лише за останні 10 днів у різних районах Чернігівщини загинуло 14 активістів. Вбивства, які охопили майже всі райони. Говорячи про мотиви такого явища, можна вказати на особисту помсту, ідейне неприйняття представників більшовицької влади в особі членів КНС, голів сільрад та інших привілейованих представників влади. Ці події відбувалися на тлі мовчання селянства та млявої реакції міліції, що призводило до того, що «зароджується в селянських головах зневіра в міць радвлади й силу ревзаконности» ${ }^{27}$.

Розглядаючи політичні настрої селянства на підставі аналізу більшовицької преси, автор «Хроніки» аналізує відносини селянства та робітництва. Вказується на те, що більшість робітників були взяті з сіл. Через це їм важко пристосуватися до виробничих обставин. Для того, щоб боротися із селянськими настроями, влада намагається залучити таких робітників до профспілок, що виходить погано 28. У селах України з метою поширення офіційної пропаганди селян силоміць змушують передплачувати більшовицьку пресу, яка не становить для селянина авторитету - «не читається і валяється з нерозрізаними сторінками» 29 . Щодо ставлення селянства до комнезамів - ці організації для селянина не $є$ авторитетними, у правліннях низової кооперації багато представників заможних. Автор «Хроніки» вказує на те, що кошти, виділені на функціонування КНС, не виправдали себе 30.

У рубриці «Хроніка» на шпальтах тижневика містяться матеріали, присвячені різним культурницьким подіям в Україні, науковим досягненням у галузі мовознавства, історії, археології, проблемам збереження пам'яток архітектури, функціонуванню культурно-просвітницьких закладів ${ }^{31}$. Вказана інформація у журналі часто грунтується на підставі вивчення комуністичної періодики в Україні.

\footnotetext{
24 Б. 3 того боку // Тризуб. 1930. Ч. 5. С. 18.

25 Степовик. Лист з України // Тризуб. 1926. Ч. 22. С. 13.

26 Хроніка // Тризуб. 1926. Ч. 22. С. 27.

27 Хроніка // Тризуб. 1927. Ч. 6. С. 12.

28 Хроніка // Тризуб. 1927. Ч. 3. С. 23.

29 Хроніка // Тризуб. 1927. Ч. 4. С. 18.

30 Хроніка // Тризуб. 1927. Ч. 4. С. 19.

31 Хроніка // Тризуб. 1926. Ч. 55. С. 25-30; Хроніка // Тризуб. 1926. Ч. 58. С. 16-22; Хроніка // Тризуб. 1927. Ч. 68. С. 19-22; Хроніка // Тризуб. 1930. Ч. 1-2. С. 24-28.
} 
У часописі «Тризуб» знаходимо цінний матеріал у рубриці «Лист селянина з Ставропільщини». Для авторів видання, ця територія, заселена нащадками переселенців з України, не розглядається як нерідна, а, скоріше, як невід'ємна складова українських земель. У мові цієї рубрики чимало русизмів або суржику. Та й автор допису пише про те, як «у нас в Росії. Докладніше доцільно навести цитату мовою оригіналу, що розкриває трагізм селянської душі, біду, що позначилася в уяві селянина, навіть, на явищах природи. «У нас зараз відколи советська власть, то й природа робе революцію: просто так скапризилась природа, що й не знаю як і сказать. Во первих, що не така весна як бувало до революційного времня, а друге повірте, що не так співають пташки, як колись кракали, словом на що усе загорумляно, зажурено, як та рослина, що на неї ніколи сонце не зазирає, бо стоїть вона в тіні де небудь... Лучче моліться Богу, як що він тільки $\epsilon$, щоб сохранив кажду державу від таких людей, що через котрих проісходить така розруха, біззаконство, злодійство, обман всякого рода, як тепер у нас в Росії».32

У наступних номерах «Тризуба» у вказаній рубриці мова йде про те, що масштаби поширення злочинності та розбою важко описати. Дописувач пише про те, що на судах звинувачені злодії часто намагаються виправдатися посиланням на те, що саме Ленін навчив їх грабувати й убивати. Ставлення до солдатів у селі, у порівнянні $з$ дореволюційними часами, край непривітне. Колишніх військовослужбовців, що повернулися до рідної домівки, розглядають як відступників - «І от так спротивилися всім советські салдати, а того, що як іде з дому на службу, то нехай хоч який розумний, то там з нього зроблять розвратного. Словом, що зроблять з його не чоловіка, а просто чорта. Їй Богу, від кожного родителя чуєш таке: - Е лучче б ти сину і зовсім не вернувся, ніж ти вернишся та будеш мені проповідувати те та те...»33.

На сторінках тижневика «Тризуб» з'являються аналітичні матеріали, в яких автори намагаються критично висвітлити соціальні, політичні процеси в Україні у 1920х роках. Так, в одній публікації вказується про те, що в умовах більшовицької системи порядкування промисловість і сільське господарство $\epsilon$ непримиренними ворогами. Індивідуальна власність, яка панує у сільському господарстві, постійно зазнає утисків та обмежень з боку держави. Промисловість $є$ цілковито бюрократизована, вона цілком залежить від індивідуальних господарів, з якими вона перебуває не просто у складних відносинах - мова йде про війну двох половин народного господарства. На думку автора, така промисловість $€$ «неприродним будинком», який має розвалитися. Або більшовики соціалізують сільське господарство, або промисловість розвалиться. Станом на 1927 р. індивідуальне господарство шляхом самообмеження, намаганням впливати на ціни веде боротьбу з комунізмом, а «большевики вірною ходою... йдуть до своєї смерти» ${ }^{34}$. Як показали подальші події, до смерті йшли не більшовики, а мільйони українських селян, приречені комуністами на жахливий голод на початку 1930-х років. У вказаній статті для нас цікаво в даному контексті не особливості функціонування радянської економіки в УСРР, а те, що ворожнеча промисловості та сільського господарства позначилася на відносинах між містом і селом, вплинула на формування стереотипів та упереджень у ставленні одне до одного їхніх мешканців, на повсякденне життя людей. «...На Вкраїні повстало два

\footnotetext{
32 Лист селянина з Ставропільщини // Тризуб. 1926. Ч. 39. С. 18.

33 Лист селянина з Ставропільщини // Тризуб. 1927. Ч. 6. С. 25.

34 Заташанський І. Сільське господарство й большевицькі «успіхи» в ньому // Тризуб. 1927. Ч. 14. C. 11.
} 
ворожих табори, що взаємно себе ненавиділи. Менший, але ліпше організований, мійський пролетаріят в своїй масі ворожий не тільки з соціального, але здебільшого й з національного боку до настроїв українських широких селянських мас...»35.

На сторінках «Тризуба» з'являлися критичні статті щодо розвитку української літератури на підвладних більшовикам українським землям ${ }^{36}$. Автор публікації дає невтішну характеристику літературному процесу: «все те, що нормальна людськість культурного світу вважає за ненормальне, гріховне, підле, кримінальне, підступне, провокаційне, гидке й огидне - все це являється предметом вихваляння і улюбленими темами, за якими «ходить популярність» та захоплення критиків» ${ }^{37}$. Дістається від автора публікації й театральним діячам на підрадянській Україні. Наприклад, «галицького запроданця» Леся Курбаса звинувачено у намаганні знищити український національний театр 38 . Критичні зауваги щодо діяльності цього театрального діяча й українського театру, що пішов на угоду з більшовизмом, містяться і в інших публікаціях часопису ${ }^{39}$.

3 кінця 1920-х років матеріалів, присвячених соціокультурним процесам, повсякденному життю в Україні на сторінках «Тризуба» стає менше. Матеріали з життя української еміграції, нариси з ідеології визвольного руху, з проблем міжнародного життя починають значно переважати. Це можна пояснити тривалою відірваністю дописувачів від українських земель, перешкоди, вчинені більшовиками для унеможливлення зв'язків українців по різний бік кордону.

Таким чином, можна дійти думки, що на сторінках тижневика «Тризуб» у 20-х роках XX ст. публікувалися матеріали, що їх можна розглядати як джерела 3 дослідження соціокультурних процесів, повсякденного життя в Україні в умовах більшовицького панування. Тематика публікацій стосувалася різноманітних сфер життя української спільноти в УСРР: розвитку культури, внутрішнього світу людини, сприйняття дійсності, тлумачення змін у природі крізь призму суспільних перетворень, відносини мешканців міста і села, становище різних прошарків суспільства.

\section{REFERENCES}

Bohuslavskyi, 0. (2008). Presa mizhvoiennoi ukrainskoi emihratsii i borotba za nezalezhnist Ukrainy: istorychnyi shliakh, dosvid, dyskusii [The Press of the inter-war Ukrainian emigration and the struggle for Ukraine's independence: historical way, experience, discussions]. Zaporizhzhia: Prosvita [in Ukrainian].

Hrynenko, 0. (2009). Materialy zhurnalu «Tryzub» pro rozsliduvannia vbyvstva Symona Petliury [Materials of the magazine «Tryzub» about the investigation of the assassination of S. Petliura (19261928)]. Ukrainskyi istorychnyi zhurnal, 3, 34-43 [in Ukrainian].

Kosyk, V. (2000). Symon Petliura [Symon Petliura]. Lviv [in Ukrainian].

Mavrin, 0. (2010). Zhurnal «Tryzub» u hromadskomu y politychnomu zhytti ukrainskoi emihratsii u Franysii mizhvoiennoho periodu [Magazine «Tryzub» is in public and political life of Ukrainian emigration in France of intermilitary period]. In Naukovi zapusky. Zbirnyk prats molodykh vchenykh ta aspirantiv, 20 (pp. 346-356). Kyiv [in Ukrainian].

Narizhyi, S. (1942). Ukrainska emihratsiia. Kulturna pratsia ukrainskoi emihratsii mizh dvoma svitovymy viinamy [Cultural labour of Ukrainian emigration is between two world wars]. Praha [in Ukrainian].

\footnotetext{
35 Слобожанський В. «Український» пролетаріят показує справжнє обличчя // Тризуб. 1926. Ч. 58. C. 12.

36 І.К. Підступне отруїння української душі // Тризуб. 1927. Ч. 68. С 7-13.

37 І.К. Підступне отруїння української душі // Тризуб. 1927. Ч. 70. С. 17.

38 І.К. Підступне отруїння української душі // Тризуб. 1927. Ч. 70. С. 19.

39 Бурахович В. Муляє очі (кілька слів про Український Народній Театр) // Тризуб. 1927. Ч. 65. C. 8-12.
} 
Piskun, V. (2015). Uchast uriadu UNR v emihratsii u prometeivskomu rusi: politychnyi, terytorialnyi ta indyvidualnyi vymiry [Participating of government of UNR in emigration in Prometheus monument: political, territorial and individual measuring]. Slavistychna zbirka, 1, 232-247 [in Ukrainian].

Savchenko, V. (2016). Symon Petliura [Symon Petliura]. Kyiv: Nora-Druk [in Ukrainian].

Zhyvotko, A. (1989-90). Istoriia ukrainskoi presy [History of the Ukrainian press]. Miunkhen [in Ukrainian].

Yas, 0. (2013). «Tryzub» [«Tryzub»]. In Entsyklopediia istorii Ukrainy, T. 10. (p. 151). Kyiv: Naukova dumka [in Ukrainian].

\section{Oleksandr Vovk}

(Sumy State Pedagogical University named after A.S. Makarenko, Sumy, Ukraine)

ORCID: https://orcid.org/0000-0001-7071-8964

\section{The Magazine of Ukrainian Emigration «Trident» as a Source of Study of Social and Cultural Processes and the Everyday Life in Ukraine under the Bilshovyks Authority} (the 1920s)

A weekly magazine of Ukrainian emigration «Trident» as a source for studying social and cultural processes and everyday life in Ukraine under the Bilshovyks authority in the 20s of the $20^{\text {th }}$ century is analyzed in the paper. It has been found out that the materials published in «Trident» were devoted to the problems of the life of Ukrainian emigration and related to social and political, ethnonational, historical, economic, and art issues. Materials of Ukrainian political and public figures, documents of the State Center of the UNR in exile, reviews, and chronicle were published in the magazine.

Most historians considered «Trident» in the life's context of Ukrainian emigration, and not as an informative source about social and cultural processes in Ukraine under the Bilshovyks occupation. The objective of the paper is to prove that the magazine could be considered as a source for studying the everyday life of Ukrainians in the Ukrainian SSR, and social and cultural processes under the Bilshovyks occupation.

As a result of the study, it is possible to conclude that materials published on the pages of the weekly magazine «Trident» in the 20 s of the $20^{\text {th }}$ century could be considered as the sources for studying social and cultural processes, and everyday life in Ukraine under the Bilshovyks rule. The subject matters of the publications covered the various spheres of Ukrainian community life in the Ukrainian SSR. In particular, it was said about the development of culture; the formation of a person's inner world, and its transformation under the influence of the life circumstances; person's perception of reality; human interpretation of nature changes through the prism of social transformations; the relations between the city and the village in Ukraine; the situation in various strata of Ukrainian society. The main heads of «Trident» entitled «A Letter from Ukraine», «A Wind from Ukraine», contained interesting information, described by eyewitnesses of events in Ukraine. The main head «Chronicle» contained materials devoted to various cultural events in Ukraine, scientific achievements in the fields of linguistics, history, archeology, problems of conservation of architectural monuments, the functioning of cultural and educational institutions. On the pages of the weekly magazine «Trident» appeared analytical materials in which the authors critically highlighted the social and political processes in Ukraine in the 1920s.

Keywords: magazine, weekly magazine, social and cultural process, everyday life, Bilshovyks 